\title{
Natural Products as Leads for Anticancer Drug Discovery: Discovery of New Chemotypes of Microtubule Stabilizers through Reengineering of the Epothilone Scaffold
}

\author{
Karl-Heinz Altmannª, Frédéric Cachoux ${ }^{\mathrm{b}}$, Fabian Feyenc, Jürg Gertsch ${ }^{\mathrm{d}}$, \\ Christian N. Kuzniewski ${ }^{a}$, and Markus Wartmann ${ }^{\mathrm{e}}$
}

\begin{abstract}
Dedicated to Professor Daniel Belluš on the occasion of his 70th birthday
Abstract: Epothilones are bacterial macrolides with potent microtubule-stabilizing and antiproliferative activity, which have served as successful lead structures for the discovery of several clinical candidates for cancer treatment. Overall, seven epothilone-type agents have been advanced to clinical evaluation in humans so far and one of these has been approved by the FDA in 2007 for clinical use in breast cancer patients. Notwithstanding these impressive numbers, however, the structural diversity represented by the collection of epothilone analogs that have been (or still are) investigated clinically is rather limited and their individual structures show little divergence from the original natural product leads. In contrast, we have elaborated a series of epothilone-derived macrolactones, whose overall structural features significantly deviate from those of the natural epothilone scaffold and thus define new structural families of microtubule-stabilizing agents. Key elements of our hypermodification strategy are the change of the natural epoxide geometry from cis to trans, the incorporation of conformationally constrained side chains, the removal of the $\mathrm{C}(3)$-hydroxyl group, and the replacement of $\mathrm{C}(12)$ with nitrogen. The latter modification leads to aza-macrolides that may be described as 'non-natural natural products'.
\end{abstract}

Keywords: Anticancer $\cdot$ Azathilones $\cdot$ Drug discovery $\cdot$ Epothilones $\cdot$ Natural product synthesis

\section{Introduction}

Natural Products (NPs) have a long-standing history as a highly prolific source of new drugs and an even larger number of unique lead structures for drug discovery and development. Based on an extensive analysis of the origin of currently employed clinical drugs, but also using a very expansive definition of the term 'natural

${ }^{\star}$ Correspondence: Prof. Dr. K.-H. Altmann ${ }^{a}$ Tel.: +41446337390

Fax: +41446331369

E-mail: karl-heinz.altmann@pharma.ethz.ch

aSwiss Federal Institute of Technology (ETH) Zürich

Institute of Pharmaceutical Sciences

ETH Hönggerberg, $\mathrm{HCl} \mathrm{H} 405$

$\mathrm{CH}-8093$ Zürich

${ }^{\mathrm{b}}$ Current address: University of Bern, Institute of

Biochemistry and Molecular Medicine, $\mathrm{CH}-3012$ Bern

${ }^{c}$ Current address: Carbogen-Amcis AG, $\mathrm{CH}-5502$

Hunzenschwil

${ }^{\mathrm{d} C}$ Current address: Pierre Fabre Research Center,

F-81106 Castres Cedex, France.

eNovartis Institutes for Biomedical Research,

DA Oncology, $\mathrm{CH}-4002$ Basel product', it has been suggested that $>60 \%$ of our small molecule-based armamentarium for pharmacotherapy is derived from NPs, either directly or indirectly. ${ }^{[1]}$ Other analyses suggest these numbers to be lower, ${ }^{[2]}$ but the fact remains that NPs have been and will continue to be an important pool of physical leads, but also of structural inspiration, for drug discovery. It has been argued that the unique potential of NPs to act upon many relevant drug targets is related to a built-in ability to bind to biological macromolecules, as the result of an evolutionary selection process. ${ }^{[3]}$ In combination with the concept of the conserved nature of ligand binding sites in proteins ${ }^{[4]}$ the perception of NPs as pre-validated protein ligands has led to the concept of 'biology-inspired synthesis' or BIOS as a new and highly success-prone strategy for lead discovery. ${ }^{[5]}$ This approach has further expanded the scope of NP-based lead finding, by adding to the previously developed 'diversity-oriented synthesis' or DOS strategy, ${ }^{[6]}$ which entails the synthesis of diverse libraries of complex LMW molecules with NP-like structural characteristics.
BIOS as well as DOS involve the synthesis of compound collections which may subsequently be screened for activity in a variety of bio-assays; alternatively, it could be envisioned that new chemotypes of NP-like lead structures for a specific, pre-defined therapeutic target may be evolved from existing, biologically active NPs through extensive structural modifications. ${ }^{[7]}$ These would not be limited to simple peripheral changes, as they are often present in semi-synthetic NP derivatives, but would also involve modifications of the core or scaffold structure, thus producing new structural templates for drug discovery. In a very general sense, one might think of this strategy as the synthesis-based equivalent to the discovery of a new natural product with a specific biological activity.

Due to our long standing interest in epothilones as lead structures for anticancer drug discovery, we have tried to apply these ideas to the creation of new and unique hypermodified epothilone analogs (i.e. molecules with very limited, if any, structural similarity with the original epothilone scaffold). ${ }^{[7]}$ The natural products epothilone (Epo) A (1) and B (2) (Fig. 1) 
are potent inhibitors of human cancer cell proliferation in vitro and of tumor growth in vivo. ${ }^{[8,9]}$ The antitumor activity of Epos is based on a taxol-type mechanism of action, which involves the stabilization of microtubules and the suppression of microtubule dynamics; ${ }^{[10]}$ at the cellular level the interference with microtubule functionality leads to cell cycle arrest in mitosis and programmed cell death (or apoptosis). The lead potential of epothilones for the development of new anticancer agents has been explored extensively and at least seven epothilone-derived agents have entered clinical evaluation in humans, including the natural product Epo B (Fig. 2). [11] One of these analogs, the Epo B lactam BMS247550 (ixabepilone, Ixempra ${ }^{\circledR}$ ) has been approved for the treatment of metastatic and advanced breast cancer by the US FDA in 2007. ${ }^{[12]}$ At the structural level, all of the clinical epothilones are still closely related to Epo B (2), i.e. there is little structural differentiation from the original natural product lead (Fig. 2). As illustrated by the example of ixabepilone such small structural changes can suffice to produce meaningful and favorable changes in overall pharmacological profile; in general, however, the availability of more structurally diverse analogs would be highly desirable, as they may offer a higher a priori potential for pharmacological distinction from the starting natural product.

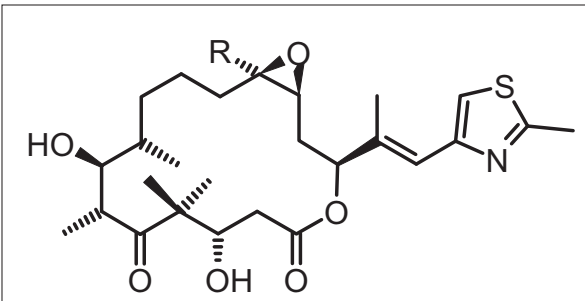

$$
\begin{aligned}
& \text { Epo A (1): } \mathrm{R}=\mathrm{H} \\
& \text { Epo B (2): } \mathrm{R}=\mathrm{CH}_{3}
\end{aligned}
$$

Fig. 1. Molecular structures of the major natural epothilones.

This article will highlight some of our efforts on the evolution of hypermodified epothilone analogs and it will illustrate that the reengineering of the natural epothilone manifold can indeed lead to new, structurally distinct chemotypes of microtubulestabilizing agents. At a more general level some of these compounds may be regarded as 'non-natural natural products' that retain most of the (two-dimensional) structural features of the NPlead; at the same time they are structurally unique, as they are outside of the general scope of nature's biosynthetic machinery for polyketide biosynthesis.

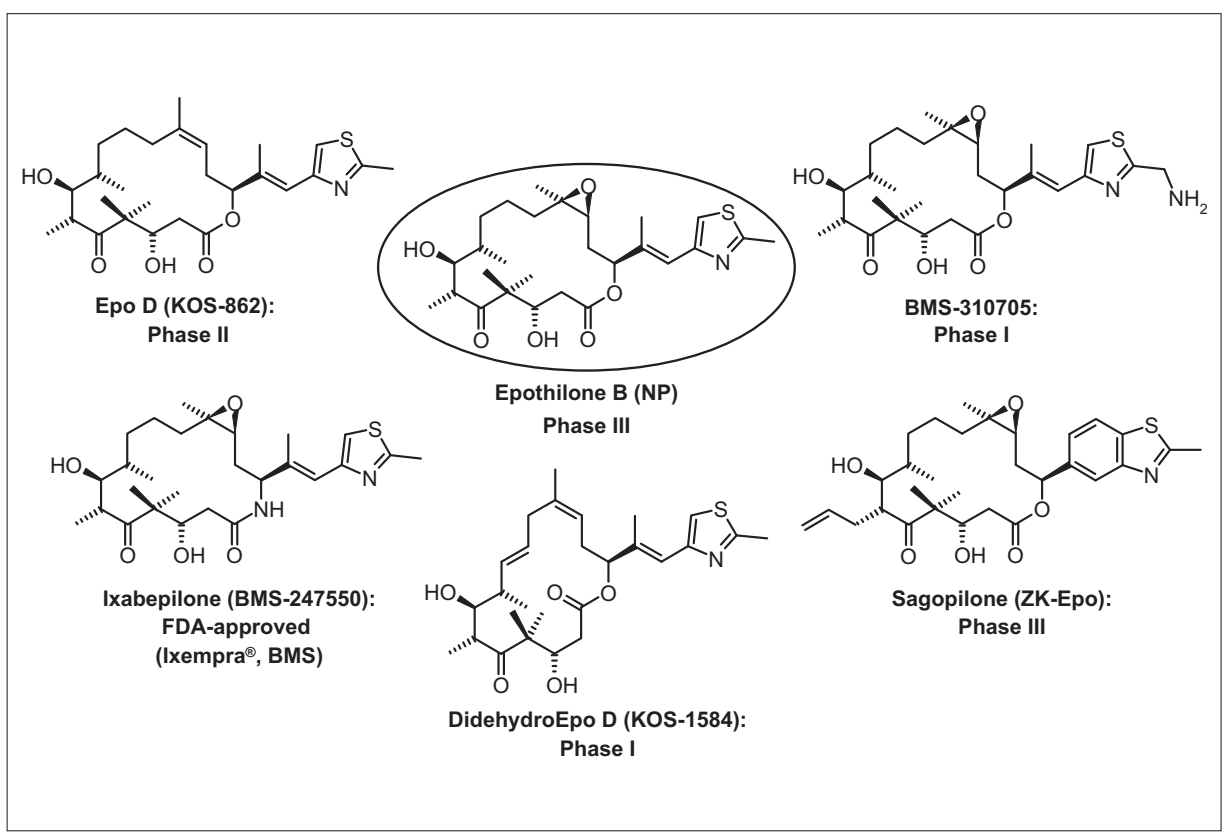

Fig. 2. Epothilone-type agents in clinical development or approved for clinical use. The figure does not include Epo B derivative ABJ879; the development of this compound was terminated after Phase I (Novartis).

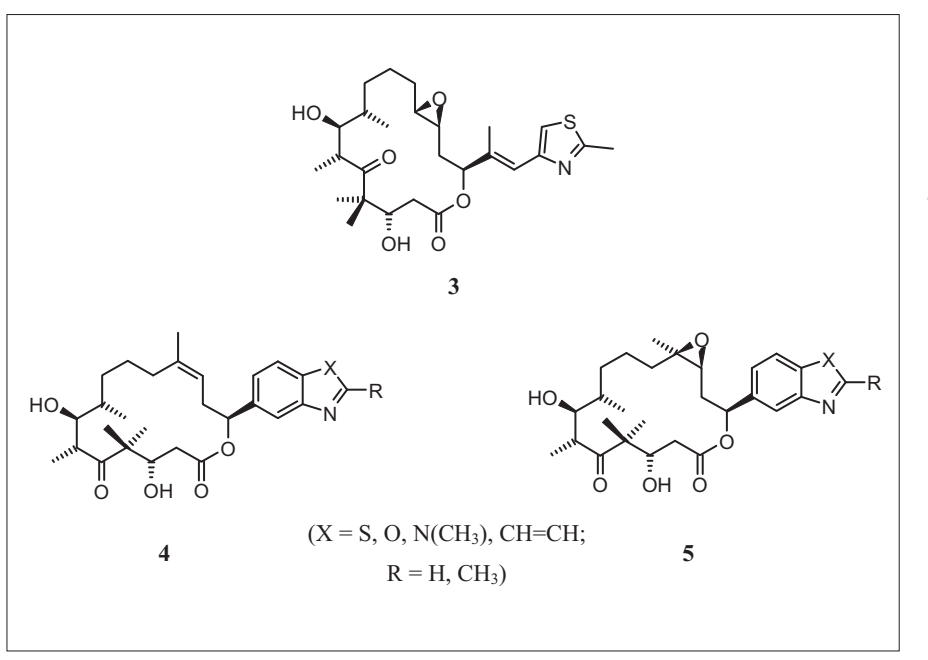

Fig. 3. Epothilone analogs with high antiproliferative activities. Points of departure for the development of hypermodified epothilone analogs.

\section{Polyketide-based Analogs}

The design of the more advanced target structures that we have investigated as part of this program was based on the results of SAR work for Epos that we had previously conducted in our laboratory. More specifically, this had involved i) changing the geometry of the $\mathrm{C}(12), \mathrm{C}(13)$ epoxide moiety from cis to trans and ii) the rigidification of the $\mathrm{C}(15)$ side chain through incorporation of a phenyl linker between the heterocycle and the macrolactone ring. Thus, the in vitro antiproliferative activity of $12 S, 13 S$-trans-Epo A (3) (Fig. 3) is comparable with (if not slightly higher than) that of natural Epo A (1). ${ }^{[13]}$ Rigidification of the $C(15)$ side chain as in analogs of type 4 or 5 (Fig. 3) generally leads to enhanced cellular potency; out of the limited number of examples investigated, this effect was most pronounced for a dimethyl-benzimidazole side chain (Fig. 3, $\left.\mathrm{X}=\mathrm{N}\left(\mathrm{CH}_{3}\right), \mathrm{R}=\mathrm{CH}_{3}\right){ }^{[14]}$ This particular modification was thus selected as the standard structure in the design of hypermodified epothilone analogs. ${ }^{[15]}$

Combining the activity-enhancing dimethyl-benzimidazole side chain with a trans-EpoAcoremacrolactoneled to analog $\mathbf{1 4}$ as an advanced target structure for synthesis and biological evaluation (Scheme 1). ${ }^{[15]}$ Following a strategy that we had successfully employed in the synthesis of trans-Epo A (3), ${ }^{[13]}$ the synthesis of $\mathbf{1 4}$ was based on the Suzuki-Miyaura coupling of olefin 9 and vinyl iodide 8 , which produced the desired fully protected seco acid in moderate, but still practical yield (55\%). ${ }^{[15]}$ Vinyl iodide 8 was prepared from aldehyde 6 through Takai reaction, which initially gave an inseparable 5/1 mixture of (TBSprotected) $E$ - and $Z$-vinyl iodides (7). From this mixture the almost pure isomer $\mathbf{8}$ 


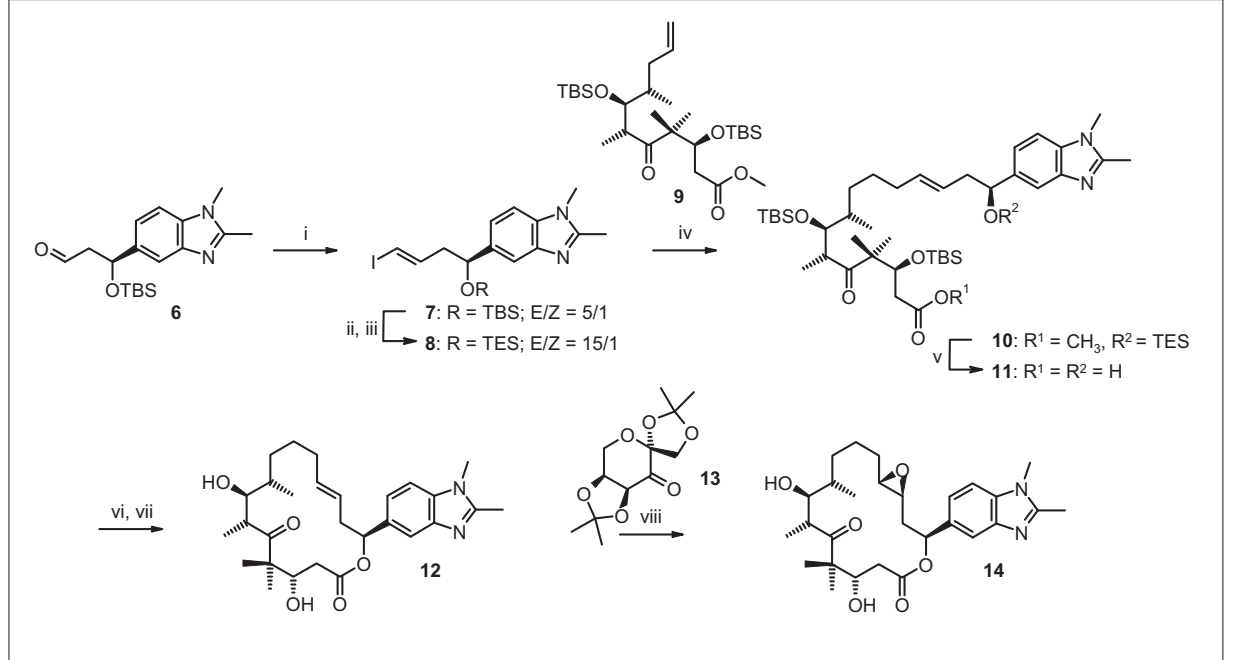

Scheme 1. i. $\mathrm{CHI}_{3}, \mathrm{CrCl}_{2}$ (8 equiv), dioxane/THF 6/1, 62\%. ii. CSA, $\mathrm{CH}_{2} \mathrm{Cl}_{2} / \mathrm{MeOH}$, crystallization from $\mathrm{CH}_{2} \mathrm{Cl}_{2} /$ hexane/MeOH, $43 \%$ (92\% for $5 / 1$ mixture of $E / Z$ isomers before crystallization). iii. TES-Cl, imidazole, DMF, $0{ }^{\circ} \mathrm{C}, 90 \mathrm{~min}, 97 \%$. iv. a) Olefin 9, 9-BBN, THF, r.t., 2h (solution A); b) addition of solution $\mathrm{A}$ to a mixture of $\mathrm{Cs}_{2} \mathrm{CO}_{3}, \mathrm{PdCl}_{2}(\mathrm{dppf})_{2}, \mathrm{Ph}_{3} \mathrm{As}$, vinyl iodide $8, \mathrm{DMF},-10{ }^{\circ} \mathrm{C} \rightarrow$ r.t., 16 h, $55 \%$. v. $\mathrm{LiOH}$ (6 equiv), $i-\mathrm{PrOH} / \mathrm{H}_{2} \mathrm{O} 4 / 1,50{ }^{\circ} \mathrm{C}, 7$ h, $78 \%$. vi. $2,4,6-\mathrm{Cl}_{3} \mathrm{C}_{6} \mathrm{H}_{2} \mathrm{C}(\mathrm{O}) \mathrm{Cl}, \mathrm{Et}_{3} \mathrm{~N}$ THF, $0{ }^{\circ} \mathrm{C}, 15 \mathrm{~min}$, then dilution with toluene and addition to a solution of DMAP in toluene, r.t. $1 \mathrm{~h}, 93 \%$. vii. $\mathrm{HF} \bullet$ pyridine, THF, r.t., $8 \mathrm{~h}, 80 \%$. viii. Oxone ${ }^{\circledR}$, ketone $13, \mathrm{Bu}_{4} \mathrm{~N}\left(\mathrm{HSO}_{4}\right)$ (cat), $\mathrm{K}_{2} \mathrm{CO}_{3}$, $\mathrm{MeCN} / \mathrm{DMM} / 0.05 \mathrm{M} \mathrm{Na}_{2} \mathrm{~B}_{4} \mathrm{O}_{7} \bullet 10 \mathrm{H}_{2} \mathrm{O}$ in $4.10^{-4} \mathrm{M} \mathrm{Na}_{2}$ EDTA $1 / 1 / 1.3,0{ }^{\circ} \mathrm{C}, 3 \mathrm{~h}, 70 \%$.

$(E / Z$-ratio $>15)$ was obtained in $43 \%$ yield (based on 6) by conversion into the corresponding mixture of free alcohols, careful crystallization, and subsequent reprotection. Saponification of the ester moiety in the coupling product was accompanied by concurrent cleavage of the TES group on $\mathrm{C}(15)-\mathrm{O}$ and the resulting seco acid was elaborated to the desired analog $\mathbf{1 4}$ through Yamaguchi macrolactonization, TBS-ether cleavage, and finally epoxidation of the $\mathrm{C}(12), \mathrm{C}(13) E$ double bond in macrolactone 12 with excess oxone in the presence of 0.8 equiv of ketone 13. ${ }^{[16]}$ An $8 / 1$ mixture of epoxide isomers was obtained in the latter step in $70 \%$ yield (after flash chromatography), from which $\mathbf{1 4}$ was isolated in pure form and 53\% overall yield through preparative HPLC. ${ }^{[15]}$ The yield of the epoxidation step $(\mathbf{1 2} \rightarrow \mathbf{1 4})$ was substantially higher than the yield we had obtained previously for the conversion of trans-Epo C (Epo C = 12,13-deoxyEpo A) into trans-Epo A (3) under similar conditions (13\%). [13]

As illustrated by the data shown in Table 1, trans-Epo A analog $\mathbf{1 4}$ is a potent inhibitor of human cancer cell growth in vitro, whose antiproliferative activity is comparable to that of Epo B (2) as the most potent natural epothilone (and, thus, significantly higher than that of Epo A (1)). The compound appears to be a moderately efficient substrate for the P-gp efflux pump, based on its reduced activity against the P-gp-overexpressing KB-8511 line ( $c a .5$-fold; ${ }^{[15]}$ data not shown). As will be discussed below, this finding has led to the design of new analogs which are not limited in their cellular activity by P-gp mediated drug efflux.

In a next modification cycle we then investigated the 3-deoxy analog of $\mathbf{1 4}$, i.e. compound 16 (Fig. 4), [17] which now accumulates three distinct types of structural changes relative to the parent epothilones. We had previously shown that the removal of the $\mathrm{C}(3)-\mathrm{OH}$ group as such, although leading to reduced cellular activity and microtubule binding affinity, was reasonably well tolerated ( $c f$. e.g. analog 15, Fig. 4 , Table 1). ${ }^{[18]}$ These findings were subsequently rationalized by structural studies on complexes between tubulin and Epo A (1), 3-deoxyEpoA (15), and also 3-deoxy-2,3-dehydroEpoA (15a), respectively, which showed that all three compounds adopt virtually the same bioactive conformation (M. Erdelyi, T. Carlomagno, K.-H. Altmann et al., unpublished data; see also ref. [18]). The presence of the $\mathrm{C}(3)-\mathrm{OH}$ group, at least in cis epoxide-based epothilones, thus, has no significant impact on the preferred conformational space occupied by these macrolides.

As shown in Scheme 2, the key transformations in the preparation of analog $\mathbf{1 6}$ were the Suzuki-Miyaura coupling of olefin 17 with vinyl iodide 8, Yamaguchi macrolactonization of a partly protected seco acid, and finally epoxidation of the $\mathrm{C}(12)-\mathrm{C}(13)$ double bond in deprotected macrolactone 18. ${ }^{[17]}$ In analogy to the transformation of $\mathbf{1 2}$ to $\mathbf{1 4}$ (Scheme 1), the epoxidation step involved the use of catalyst $\mathbf{1 3}^{[16]}$ and provided $\mathbf{1 6}$ as a single isomer in $65 \%$ isolated yield after simple flash chromatography $(86 \%$ based on recovered starting material). Quite remarkably, the antiproliferative activity of $\mathbf{1 6}$ is virtually identical with that of Epo A (1) or taxol (data for taxol not shown), in spite of its harboring major structural alterations relative to the native epothilone scaffold (Table 1), ${ }^{[17]}$ and the same is true for its tubulin-polymerizing activity (data not shown). However, as for analog 14, the growth inhibitory activity of $\mathbf{1 6}$ is slightly lower against the multidrug-resistant KB8511 cell line than the taxol-sensitive KB31 line $\left(\mathrm{IC}_{50}(\mathrm{~KB}-8511)=7.6 \mathrm{nM}\right) .{ }^{[17]}$

Based on the systematic analysis of the cellular activity of a series of selected epothilone analogs with different polarity (as assessed by clogP; data not shown), it ap-

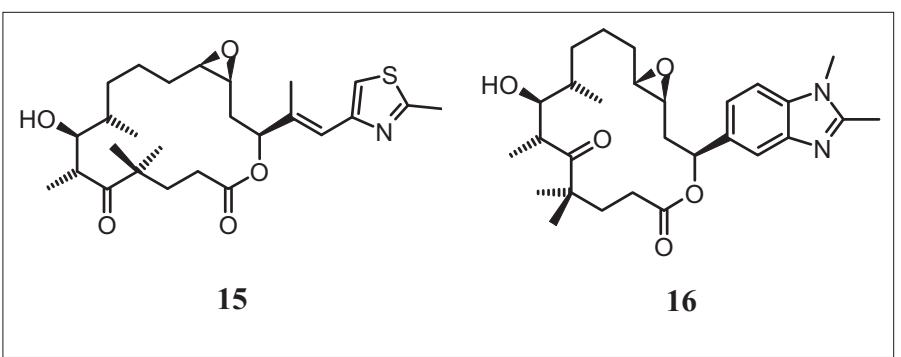

Fig. 4. Molecular structures of 3-deoxyepothilones. 


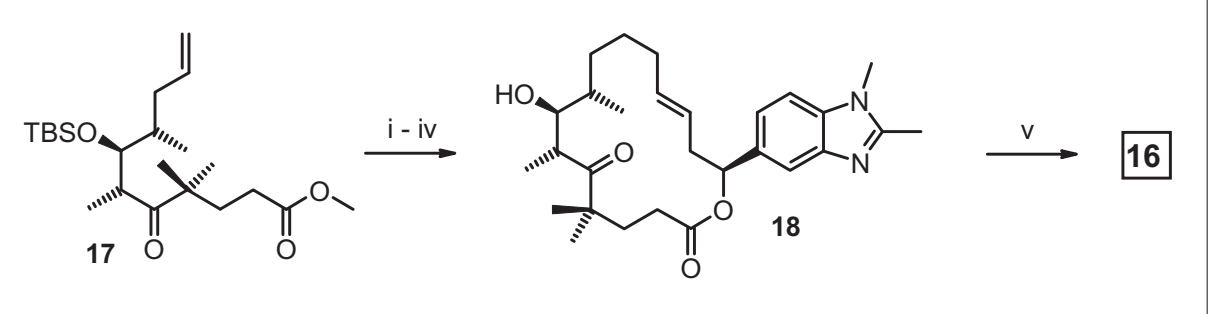

Scheme 2: i. a) Olefin 17, 9-BBN (0.8 equiv), THF, r.t., $2 \mathrm{~h}$ (solution A); b) addition of solution $\mathrm{A}$ to a mixture of $\mathrm{Cs}_{2} \mathrm{CO}_{3}$ (1.5 equiv), $\mathrm{PdCl}_{2}(\mathrm{dppf})_{2}$ (0.1 equiv), $\mathrm{Ph}_{3} \mathrm{As}$ (0.2 equiv), vinyl iodide 8 (Scheme 1, 1 equiv), $\mathrm{DMF},-10^{\circ} \mathrm{C} \rightarrow$ r.t., 16 h, $58 \%$. ii. $\mathrm{LiOH}$ (6 equiv), $\mathrm{THF} / \mathrm{H}_{2} \mathrm{O} 7 / 1$, r.t., 24 h, $76 \%$. iii. 2,4,6- $\mathrm{Cl}_{3} \mathrm{C}_{6} \mathrm{H}_{2} \mathrm{C}(\mathrm{O}) \mathrm{Cl}, \mathrm{Et}_{3} \mathrm{~N}, \mathrm{THF}, 0{ }^{\circ} \mathrm{C}, 15 \mathrm{~min}$, then diluted with toluene and added to a solution of DMAP in toluene, r.t., $1 \mathrm{~h}, 71 \%$. iv. HF•pyridine, THF, r.t., 6 h, $94 \%$. v. Oxone ${ }^{\circledR}$, ketone $13(0.8$ equiv), $\mathrm{Bu}_{4} \mathrm{~N}\left(\mathrm{HSO}_{4}\right.$ ) (cat), $\mathrm{K}_{2} \mathrm{CO}_{3}, \mathrm{MeCN} / D M M / 0.05 \mathrm{M} \mathrm{Na}_{2} \mathrm{~B}_{4} \mathrm{O}_{7} \bullet 10 \mathrm{H}_{2} \mathrm{O}$ in $4 \times 10^{-4} \mathrm{M} \mathrm{Na}_{2}$ EDTA $1 / 1 / 1.3,0{ }^{\circ} \mathrm{C}, 3 \mathrm{~h}, 65 \%$ ( $86 \%$ based on recovered starting material; single isomer).
(19); $0.082 \mathrm{nM}(\mathbf{2 0}))$. In fact, 20 was found to be significantly more active against the KB-8511 line ( $c a$. 5-fold); the reasons for this phenomenon are elusive at this point, however, and care should be taken in generalizing this finding.

\section{12-Aza-epothilones}

The analysis of structural similarity on the basis of Tanimoto coefficients revealed analog $\mathbf{1 6}$ to be as different from Epo A (1) as other, unrelated, macrolidebased microtubule stabilizers, such as laulimalide or peloruside $A,[10,17]$ thus lending support to the concept that iterative peared that the reduced activity of analogs $\mathbf{1 4}$ and $\mathbf{1 6}$ against the P-gp-overexpressing KB-8511 cell line might be related to the increased polarity of these benzimidazolecontaining compounds, compared to natural epothilones incorporating the natural side chain. As a consequence, we felt that this problem could perhaps be remedied by the (structurally) simple replacement of the epoxide moiety by a cyclopropane ring, thus resulting in analogs $\mathbf{1 9}$ and $\mathbf{2 0}$ as the next generation target structures (Fig. 5). ${ }^{[19,20]}$ Chemically, however, this type of continued structural alteration of the macrolide core posed a significant challenge, as the direct cyclopropanation of macrolactone 12 ( $c f$. Scheme 1) did not deliver the desired cyclopropane with any useful degree of selectivity under a variety of conditions. ${ }^{[19]} \mathrm{We}$, therefore, had to resort to alternative strategies which involved the incorporation of the cyclopropane moiety at an earlier stage of the syntheses. For 3-deoxy analog $\mathbf{2 0}$ this entailed the stereoselective cyclopropanation of allylic alcohol 22 under Charette conditions (i.e. employing catalyst $\mathbf{2 3}^{[21]}$ ), which provided the required cyclopropane isomer $\mathbf{2 4}$ in excellent yield and as a single isomer (Scheme 3).[20] Two-carbon extension of 24 (including a series of functional group manipulations) led to olefin 26; the latter was esterified with acid $\mathbf{2 7}$ to provide diene $\mathbf{2 8}$ as a substrate for ring-closing metathesis (RCM). Ring-closure proceeded smoothly in the presence of Grubbs II catalyst to furnish the macrocyclic $E$ alkene as the only isolable isomer in $94 \%$ yield. Subsequent protecting group removal followed by hydrogenation with Crabtree's catalyst gave target structure 20. Both cyclopropane analogs 19 and 20 proved to be highly potent antiproliferative agents and, most importantly, neither compound showed any measurable activity differential between the drug-sensitive KB-31 cell line (Table 1) and its drug-resistant KB8511 variant $\left(\mathrm{IC}_{50}(\mathrm{~KB}-8511)=0.13 \mathrm{nM}\right.$

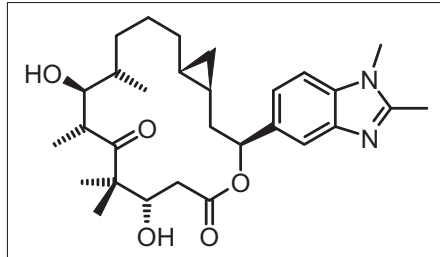

19

21

22

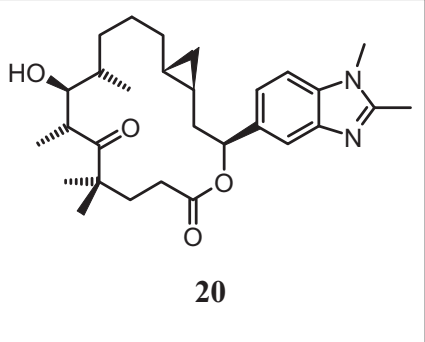

Fig. 5. Cyclopropanebased trans-Epo A analogs.
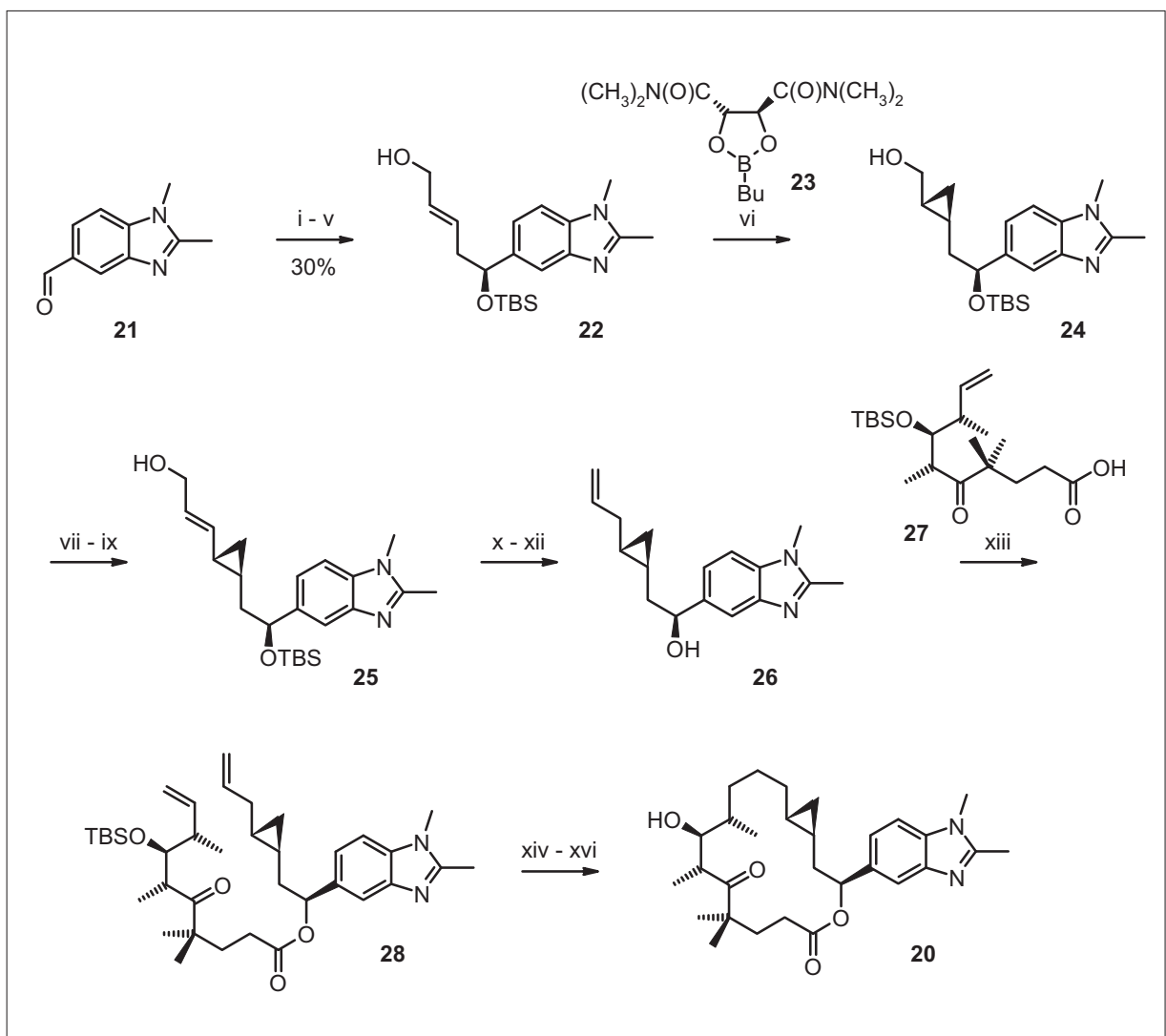

Scheme 3: i. (-)-(Ipc) $\mathrm{B}$-allyl, $\mathrm{Et}_{2} \mathrm{O},-78{ }^{\circ} \mathrm{C}, 1 \mathrm{~h}, 64 \%$. ii. TBSCl, imidazole, DMF, 95\%. iii. $\mathrm{O}_{3}, \mathrm{SMe}_{2}$ $\mathrm{MeOH} / \mathrm{CH}_{2} \mathrm{Cl}_{2} 1 / 1,-78^{\circ} \mathrm{C}, 73 \%$. iv. $\mathrm{PPh}_{3} \mathrm{CHCO}_{2} \mathrm{Et}, \mathrm{CH}_{2} \mathrm{Cl}_{2}$, r.t. v. DIBAL-H, $\mathrm{CH}_{2} \mathrm{Cl}_{2},-78^{\circ} \mathrm{C} \rightarrow 0{ }^{\circ} \mathrm{C}$, $58 \%$ over 2 steps. vi. $\mathrm{Et}_{2} \mathrm{Zn}, \mathrm{CH}_{2} \mathrm{I}_{2}$, (+)-dioxaborolane 23 (2 equiv), $\mathrm{CH}_{2} \mathrm{Cl}_{2}, 0^{\circ} \mathrm{C} \rightarrow$ r.t., quant. vii. $(\mathrm{COCl})_{2}$, DMSO, $\mathrm{NEt}_{3}, \mathrm{CH}_{2} \mathrm{Cl}_{2},-78^{\circ} \mathrm{C} \rightarrow 0{ }^{\circ} \mathrm{C}$. viii. $\mathrm{PPh}_{3} \mathrm{CHCO}_{2} \mathrm{Et}, \mathrm{CH}_{2} \mathrm{Cl}_{2}$, r.t. ix. DIBAL-H, $\mathrm{CH}_{2} \mathrm{Cl}_{2}$, $-78{ }^{\circ} \mathrm{C} \rightarrow 0{ }^{\circ} \mathrm{C}, 65 \%$ over 3 steps. x. $\mathrm{NaBH}_{4}, \mathrm{CoCl}_{2} \bullet 6 \mathrm{H}_{2} \mathrm{O}(40 \mathrm{~mol} \%)$, MeOH/DMF 1.7/1, 74\%. xi. a) o- $\mathrm{NO}_{2} \mathrm{PhSeCN}, \mathrm{PBu}_{3}$, THF; b) $\mathrm{H}_{2} \mathrm{O}_{2}(30 \%), \mathrm{NaHCO}_{3}, 30^{\circ} \mathrm{C} \rightarrow 50{ }^{\circ} \mathrm{C}, 90 \%$. xii. $\mathrm{CSA}, \mathrm{MeOH} /$ $\mathrm{CH}_{2} \mathrm{Cl}_{2} 1 / 1,0^{\circ} \mathrm{C} \rightarrow$ r.t., $74 \%$. xiii. EDC, DMAP (1 eq), $\mathrm{CH}_{2} \mathrm{Cl}_{2}$, r.t., $24 \mathrm{~h}, 84 \%$. xiv. Grubbs II (10 mol\%), toluene, $110{ }^{\circ} \mathrm{C}, 15 \mathrm{~min}, 94 \% . x v . \mathrm{CH}_{2} \mathrm{Cl}_{2} / \mathrm{TFA} 4 / 1,18 \mathrm{~h}, 80 \%$. xvi. [Ir(cod) $\left.\left(\mathrm{PCyD}_{3}\right)(\mathrm{py})\right] \mathrm{PF}_{6}$, $\mathrm{CH}_{2} \mathrm{Cl}_{2}, 0^{\circ} \mathrm{C} \rightarrow$ r.t., $62 \%$ (after prep. HPLC). 


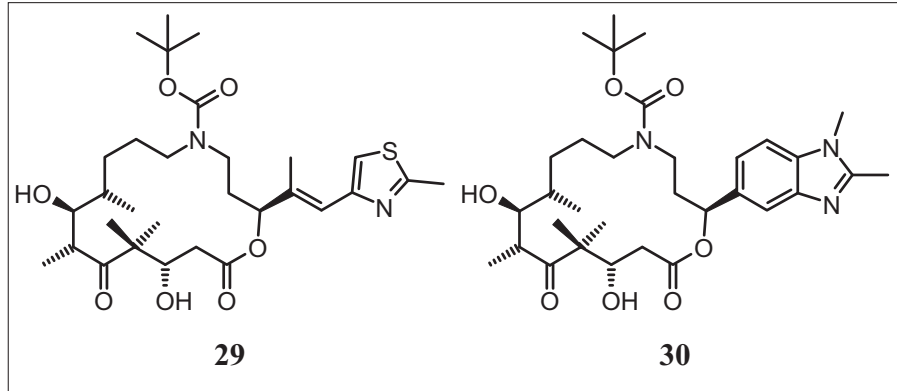

Fig. 6. 12-Azaepothilones as non-natural natural products.
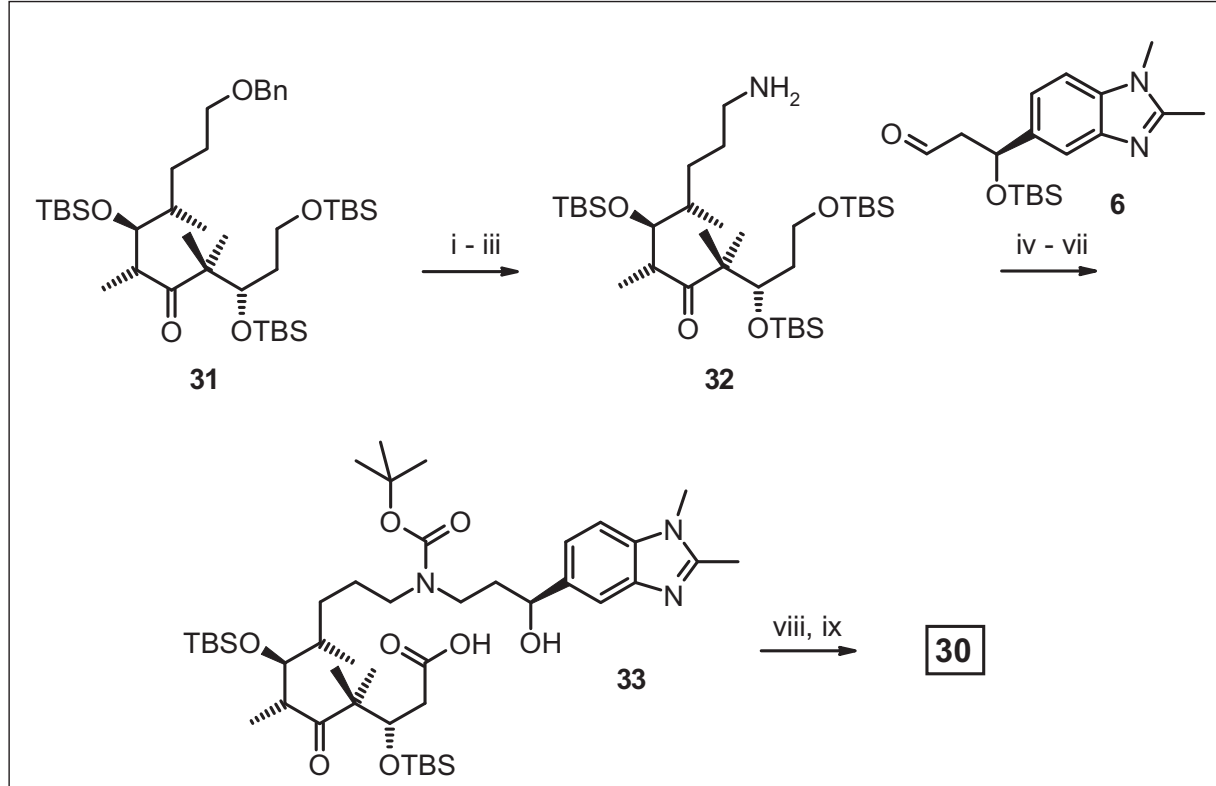

Scheme 4: i. $\mathrm{H}_{2} / \mathrm{Pd}-\mathrm{C}$, EtOAc, r.t., 62 h, 86\%. ii. $\mathrm{HN}_{3}$, DEAD, $\mathrm{PPh}_{3}$, THF, $0{ }^{\circ} \mathrm{C}, 25$ min, r.t., 30 min, 96\%. iii. $\mathrm{H}_{2} / \mathrm{Pd}-\mathrm{C}, \mathrm{MeOH}$, r.t., 3 h, 92\%. iv. a) 6 (1.1 equiv), $\mathrm{NaBH}(\mathrm{OAc})_{3}$ (1.6 equiv), $\mathrm{AcOH}(2.0$ equiv), 4- $\AA$ MS, r.t., 2.5 h; b) $\mathrm{BOC}_{2} \mathrm{O}, \mathrm{Et}_{3} \mathrm{~N}, \mathrm{THF}, 0{ }^{\circ} \mathrm{C}, 45 \mathrm{~min}, 60 \%$ (two steps). v) $\mathrm{CSA}$ (1.1 equiv), $\mathrm{CH}_{2} \mathrm{Cl}_{2} / \mathrm{MeOH} 1 / 1,0{ }^{\circ} \mathrm{C}, 3 \mathrm{~h}, 80 \%$. vi. PDC (15 equiv), DMF, r.t., 24 h, 50\%. vii. TBAF (6 equiv), THF, r.t., 24 h. viii. 2,4,6- $\mathrm{Cl}_{3} \mathrm{C}_{6} \mathrm{H}_{2} \mathrm{C}(\mathrm{O}) \mathrm{Cl}, \mathrm{Et}_{3} \mathrm{~N}$, THF, $0{ }^{\circ} \mathrm{C}, 20 \mathrm{~min}$, then diluted with toluene and added to a solution of DMAP in toluene, $75^{\circ} \mathrm{C}, 1 \mathrm{~h}, 44 \%$ (two steps). ix. HF•pyridine, pyridine, THF, r.t., $2.5 \mathrm{~h}$, then preparative HPLC, $40 \%$.

structural alterations of biologically active natural products can eventually lead to new structural scaffolds for the inhibition the original NP's biological target. However, even analogs such as $\mathbf{1 6}$ or $\mathbf{2 0}$ are still based on a regular polyketidetype macrolactone core, which is one of the defining structural features of natural epothilones. In an attempt to reach beyond such polyketide-based analogs, our efforts to develop new structural templates for microtubule stabilization have also included the design of different types of $a z a$-epothilones ('azathilones'). In these analogs one of the backbone carbon atoms is replaced with nitrogen, which disrupts the all-polyketide character of the macrocyclic backbone.[7,22-24] In light of this fundamental structural change we have termed such analogs 'non-natural natural products'[24] (vide supra). Prototypical examples of this class of epothilone analogs are depicted in Fig. 6 (29 and
30) and Scheme 4 summarizes our second generation approach to the synthesis of the side chain-modified azathilone 30. [24] This approach involved the reductive amination of aldehyde 6 with amine 32 (obtained in three steps from the known protected tetrol 31[13]) as a central step in the assembly of the hetero-aliphatic skeleton of 30. This reaction proceeded most efficiently with a slight excess of aldehyde $\mathbf{6}$ (1.1 equiv) and with $\mathrm{NaBH}(\mathrm{OAc})_{3}$ as the reducing agent in the presence of $\mathrm{AcOH}$ ( 2 equiv) and 4 - $\AA$ molecular sieves. The product of the reductive amination was not purified, but the newly formed secondary amino group was directly converted to the corresponding tert-butyl carbamate, thus avoiding the cumbersome and impractical handling of the very polar free amine. The N-BOC derivatized amine was then elaborated into seco acid $\mathbf{3 3}$ by selective cleavage of the primary TBS-ether with CSA followed by oxidation of the result- ing free alcohol with PDC and removal of the TBS protecting group from $\mathrm{C}(15)-\mathrm{O}$ with TBAF. 33 was cyclized under Yamaguchi conditions ${ }^{[25]}$ to produce bis-TBS protected 30; subsequent selective cleavage of the TBS protecting groups with $\mathrm{HF}$.pyridine gave target structure $\mathbf{3 0}$ in $40 \%$ yield (after HPLC purification).

Azathilone $\mathbf{3 0}$ is a highly potent antiproliferative agent, which inhibits the growth of different types of drug-sensitive human cancer cell lines with low $\mathrm{nM} \mathrm{IC}_{50}$ values (Table 1; other data not shown). For those cell lines investigated the compound proved to be $>60$-fold more potent against drug-sensitive human cancer cells than the corresponding parent azathilone 29 (Fig. 6 ); this potency increase is significantly higher than previously observed upon the replacement of the natural side chain by a dimethyl-benzimidazole moiety in polyketide-based analogs (2-15-fold). ${ }^{[15]}$

Given the significant structural alterations of compounds such as 29 and $\mathbf{3 0}$ relative to the natural epothilone scaffold, we felt it important to confirm that the inhibition of cancer cell growth in vitro by azathilones, as for natural epothilones, was based on a direct interaction with the cellular microtubule network. Such studies were enabled by the attachment of a fluorophoric nitro benzoxadiazol (NBD) moiety to N(12) of the azathilone macrocycle (Scheme 5), leading to analogs such as $\mathbf{3 4}$ as versatile fluorescent probes for cellular experiments. Although less potent than 29 or 30, analog 34 inhibits human cancer cell growth in vitro with sub- $\mu \mathrm{M}$ activity, thus making it a relevant tool for mecha-

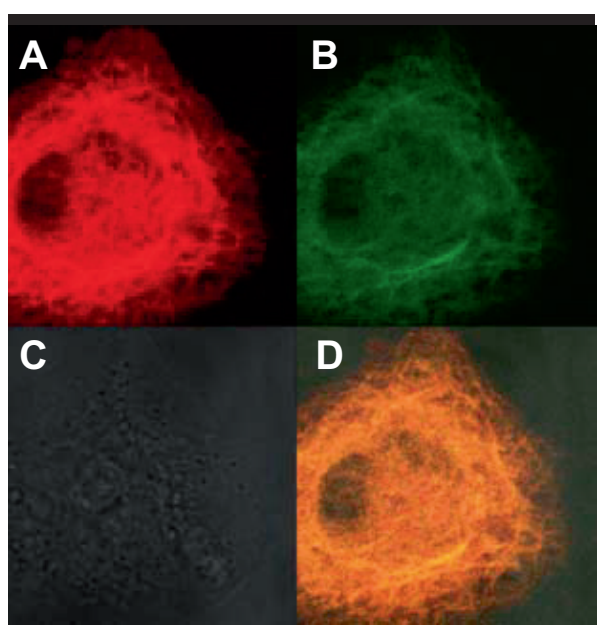

Fig. 7. Confocal fluorescence microscopy of logarithmically growing HeLa cells expressing a red fluorescent protein (RFP)- $\alpha$-tubulin fusion protein after treatment with $34(5 \mu \mathrm{M}, 2.5 \mathrm{~h})$. (A) Excitation at $561 \mathrm{~nm}$. (B) Excitation at 488 $\mathrm{nm}$. (C) Visible light (no excitation). (D) Merged images from $(A)$ and $(B)$, which illustrates that the microtubule-derived fluorescene and the compound-derived fluoresence completely colocalize. 
nistic studies. ${ }^{[26]}$ As illustrated in Fig. 7, compound 34 specifically labels cellular microtubules in HeLa cells expressing a red fluorescent protein (RFP)- $\alpha$-tubulin fusion protein in interphase cells and similar fluorescence images were also obtained with mitotic cells (data not shown). This finding strongly suggests that the antiproliferative activity of $\mathbf{3 4}$ is indeed based on its binding to cellular microtubules; it then seems reasonable to imply that this is also true for other azathilone-type cancer cell growth inhibitors. The data thus support and reinforce the results of previous studies on the mechanism of action of analog 30. ${ }^{24]}$ Unfortunately, azathilones in general have been found to be less potent against the multidrug-resistant cervical carcinoma cell line KB-8511 than the drug-sensitive KB-31 line, especially when incorporating an activity-enhancing benzimidazole side chain as in 30. ${ }^{[24]}$ However, as illustrated above for polyketide-based epothilone analogs, the susceptibility to P-gp-mediated drug efflux may be modulated through adjustments in compound polarity and this strategy could also be explored for lead structure 30.

\section{Conclusions}

The work reviewed in this article demonstrates how the iterative modification of an appropriate natural product scaffold can lead to highly potent analogs with significantly altered structural features. In the specific context of tubulin modulation compound $\mathbf{2 0}$ and related analogs may be considered to represent a new chemotype for microtubule stabilization, which, $a$ priori, should offer the same potential for pharmacological differentiation from Epo A (1) or B (2) as any newly discovered natural product microtubule stabilizer, such as laulimalide, peloruside, dictyostatin, ${ }^{[7]}$ or, as a very recent addition to this group, zampanolide. ${ }^{[27]}$ Similar conclusions apply to $\mathbf{3 0}$ and related 12-azaepothilones, which may be considered as members of a distinct group of "non-natural natural products' with unique structural features. It is also clear, however, that the overall pharmacological profile of our analogs still needs to be established in in vivo studies. Apart from this essential issue, work currently ongoing in our laboratory aims at a better understanding

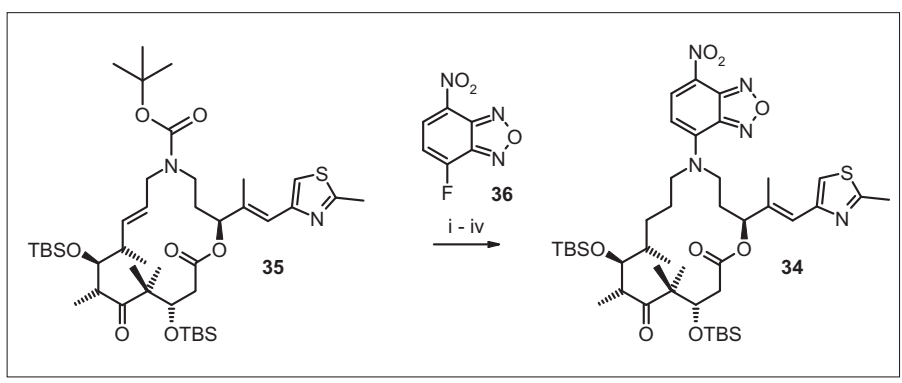

Scheme 5: i. $\mathrm{ZnBr}_{2}$, $\mathrm{CH}_{2} \mathrm{Cl}_{2}, 5 \mathrm{~h}, 94 \%$. ii. $\mathrm{KOOC}-\mathrm{N}=\mathrm{N}-\mathrm{COOK}$ $\mathrm{AcOH}, \mathrm{CH}_{2} \mathrm{Cl}_{2}$, refl., 4 h. iii. NBD-F, EtOH, refl., $15 \mathrm{~min}, 50 \%$ (2 steps). iv. HF•pyridine, THF, 2.5 h, $82 \%$. of the SAR associated with structures of type $\mathbf{2 0}$ and 30, with preliminary data indicating that the SAR for aza-epothilones does not fully parallel the SAR associated with natural epothilones.

\section{Acknowledgements}

The generous financial support of this work by the Swiss National Science Foundation (C. N. K.; project numbers 200021-107876 and 205320$117594)$ and by the ETH Zürich is gratefully acknowledged. We are also indebted to Novartis Pharma AG for a postdoctoral fellowship to F.C.

\section{Received: December 18, 2009}

[1] D. J. Newman, G. M. Cragg, J. Nat. Prod. 2007, $70,461$.

[2] A. Ganesan, Curr. Opin. Chem. Biol. 2008, 12, 306.

[3] S. Wetzel, A. Schuffenhauer, S. Roggo, P. Ertl, H. Waldmann, Chimia 2005, 61, 355 .

[4] For pertinent reviews see: a) M. A. Koch, H. Waldmann, Drug Disc. Today 2005, 10, 471; b) F. Dekker, M. A. Koch, H. Waldmann, Curr. Opin. Chem. Biol. 2005, 9, 232.

[5] A. Nören-Müller, I. Reis-Corrêa, Jr., H. Prinz, C. Rosenbaum, K. Saxena, H. J. Schwalbe, D. Vestweber, G. Cagna, S. Schunk, O. Schwarz, H. Schiewe, H. Waldmann, Proc. Natl. Acad. Sci. USA 2005, 103, 10606.

[6] M. D. Burke, S. L. Schreiber, Angew. Chem. Int. Ed. 2004, 43, 46

[7] F. Feyen, F. Cachoux, J. Gertsch, M. Wartmann, K.-H. Altmann, Acc. Chem. Res. 2008, 41, 21.

[8] For recent reviews on the chemistry and biology of epothilones see: a) K.-H. Altmann, B. Pfeiffer, S. Arseniyadis, B. A. Pratt, K. C. Nicolaou, ChemMedChem 2007, 2, 396; b) G. Höfle, H. Reichenbach, 'Anticancer Agents from Natural Products', CRC Press: Boca Raton, 2005, p 413.

[9] For a recent book on epothilones $c f$ :: Progress Chem. Org. Nat. Prod. Vol. 90, Eds. A. D. Kinghorn, H. Falk, J. Kobayashi; K.-H. Altmann, G. Höfle, R. Müller, J. Mulzer, K. Prantz, 'The Epothilones: An Outstanding Family of Anti-Tumor Agents', Springer, 2009.

[10] For a recent review on microtubule-stabilizing agents $c f:$ : K.-H. Altmann, J. Gertsch, Nat. Prod. Rep. 2007, 24, 327

[11] For a recent review on clinical studies with epothilone-derived agents see: H. M. Coley, Cancer Treat. Rev. 2008, 34, 378.
[12] For leading references on ixabepilone see: a) E. S. Thomas, H. L. Gomez, R. K. Li, H.-C. Chung, L. E. Fein, V. F. Chan, J. Jassem, X. B. Pivot, J. Klimovsky, F. Hurtado de Mendoza, B. Xu, M. Campone, G. L. Lerzo, R. A. Peck, P. Mukhopadhyay, L. T. Vahdat, H. H. Roche, J. Clin. Oncol. 2007, 25, 5210; b) F. Y. F. Lee, R. Borzilleri, C. R. Fairchild, S. H. Kim, B. H. Long, C. Reventos-Suarez, G. D. Vite, W. C. Rose, R. A. Kramer, Clin. Cancer Res. 2001, 7, 1429-1437. c) R. M. Borzilleri, X. P. Zheng, R. J. Schmidt, J. A. Johnson, S. H. Kim, J. D. DiMarco, C. R. Fairchild, J. Z. Gougoutas, F. Y. F. Lee, B. H. Long, G. D. Vite, J. Am. Chem. Soc. 2000, 122, 8890-8897. See also: http:// www.cancer.gov/cancertopics/druginfo/fdaixabepilone.

[13] K.-H. Altmann, G. Bold, G. Caravatti, D. Denni, A. Flörsheimer, A. Schmidt, G. Rihs, M. Wartmann, Helv. Chim. Acta 2002, 85, 4086.

[14] K.-H. Altmann, G. Bold, G. Caravatti, A Flörsheimer, V. Guagnano, M. Wartmann, Bioorg. Med. Chem. Lett. 2000, 10, 2765.

[15] F. Cachoux, T. Isarno, M. Wartmann, K.-H. Altmann, ChemBioChem 2006, 7, 54 .

[16] Z.-X. Wang, Y. Tu, M. Frohn, J.-R. Zhang, Y. Shi, J. Am. Chem. Soc. 1997, 119, 11224.

[17] F. Cachoux, T. Isarno, M. Wartmann, K.-H. Altmann, Angew. Chem. Int. Ed. 2005, 44, 7469 .

[18] M. Erdélyi, B. Pfeiffer, K. Hauenstein, J. Fohrer, J. Gertsch, K.-H. Altmann, T. Carlomagno, $J$. Med. Chem. 2008, 51, 1469.

[19] F. Cachoux, T. Isarno, M. Wartmann, K.-H. Altmann, Synlett 2006, 1384

[20] C. N. Kuzniewski, J. Gertsch, M. Wartmann, K.-H. Altmann, Org. Lett. 2008, 10, 1183.

[21] A. B. Charette, H. Juteau, H. Lebel, C. Molinaro, J. Am. Chem. Soc. 1998, 120, 11943.

[22] K.-H. Altmann, A. Flörsheimer, G. Bold, G. Caravatti, M. Wartmann, Chimia 2004, 58, 686.

[23] F. Cachoux, F. Schaal, A. Teichert, T. Wagner, K.-H. Altmann, Synlett 2004, 2709.

[24] F. Feyen, J. Gertsch, M. Wartmann, K.-H. Altmann, Angew. Chem. Int. Ed. 2006, 45 5880.

[25] J. Inanaga, K. Hirata, H. Saeki, T. Katsuki, M. Yamaguchi, Bull. Chem. Soc. Jpn. 1979, 52, 1989.

[26] J. Gertsch, F. Feyen, A. Büetzberger, B. Gerber, B. Pfeiffer, K.-H. Altmann, ChemBioChem 2009, 10, 2513.

[27] J. J. Field, A. J. Singh, A. Kanakkanthara, H. Tu'ikolongahau, P. T. Northcote, J. H. Miller, $J$. Med. Chem. 2009, 52, 7328. 